\title{
Importance of radiological imaging in a case of subungual glomus tumour
}

\author{
Lakshmikanth Halegubbi Karegowda, ${ }^{1}$ Poonam Mohan Shenoy, ${ }^{1}$ \\ Sathish Babu Maddukuri, ${ }^{1}$ Harsha Kyalakond ${ }^{2}$
}

'Department of Radiology, Kasturba Medical College, Manipal, Karnataka, India ${ }^{2}$ Department of Orthopaedics, Kasturba Medical College, Manipal, Karnataka, India

\section{Correspondence to}

Dr Lakshmikanth Halegubbi Karegowda,

hkkanha@gmail.com

Accepted 23 September 2014

\section{DESCRIPTION}

A 33-year-old woman presented with paroxysms of intense pain over the tip of the right middle finger of 2-year duration. Clinical examination revealed acute tenderness in the nail bed.

Radiograph of the middle finger revealed focal scalloping of the bony cortex along lateral aspect of terminal phalanx (figure 1A). Ultrasound and duplex imaging showed a small oval homogeneously hypoechoic lesion within the subungual soft tissue of the nail bed (figure 1B) with intense internal vascularity (figure 1C) and arterial waveforms (figure 1D) consistent with a vascular tumour. On MRI the lesion was isointense (to muscle) on T1 (figure 2A), hyperintense on T2 (figure 2B) and showed intense homogeneous postcontrast enhancement (figure 2C-E). These modalities also helped in precise localisation of the lesion in the dorsolateral aspect of the terminal phalanx. Following the localisation, surgery was performed with complete excision of the lesion. Histopathology of the lesion showed numerous vascular channels that were surrounded by aggregates of round epithelioid cells containing eosinophilic cytoplasm confirming it as a glomus tumour (figure 3).

Glomus tumours are rare benign hamartomatous lesions found in the reticular areas of the hand. ${ }^{1}$ About $75 \%$ of these tumours are seen in the hands and up to $65 \%$ in the tips of the digits. Although numerous clinical tests help in suspecting these lesions, they may still go undetected due to their small size leading to delay in diagnosis. ${ }^{2}$ Hence imaging plays an important role in their detection. Plain radiograph may or may not show any abnormality, especially when the lesion is very small. Ultrasound and MRI form excellent imaging modalities for detection and characterisation of the lesion as shown in this case. These modalities are also very helpful in precise localisation of the small lesion, which is imperative for the meticulous surgical planning that aids in complete removal of the lesion, and in avoiding recurrence and nail deformity. In relatively larger lesions that are clinically obvious, imaging helps in detecting the bony invasion, which is again important for the surgical decision.

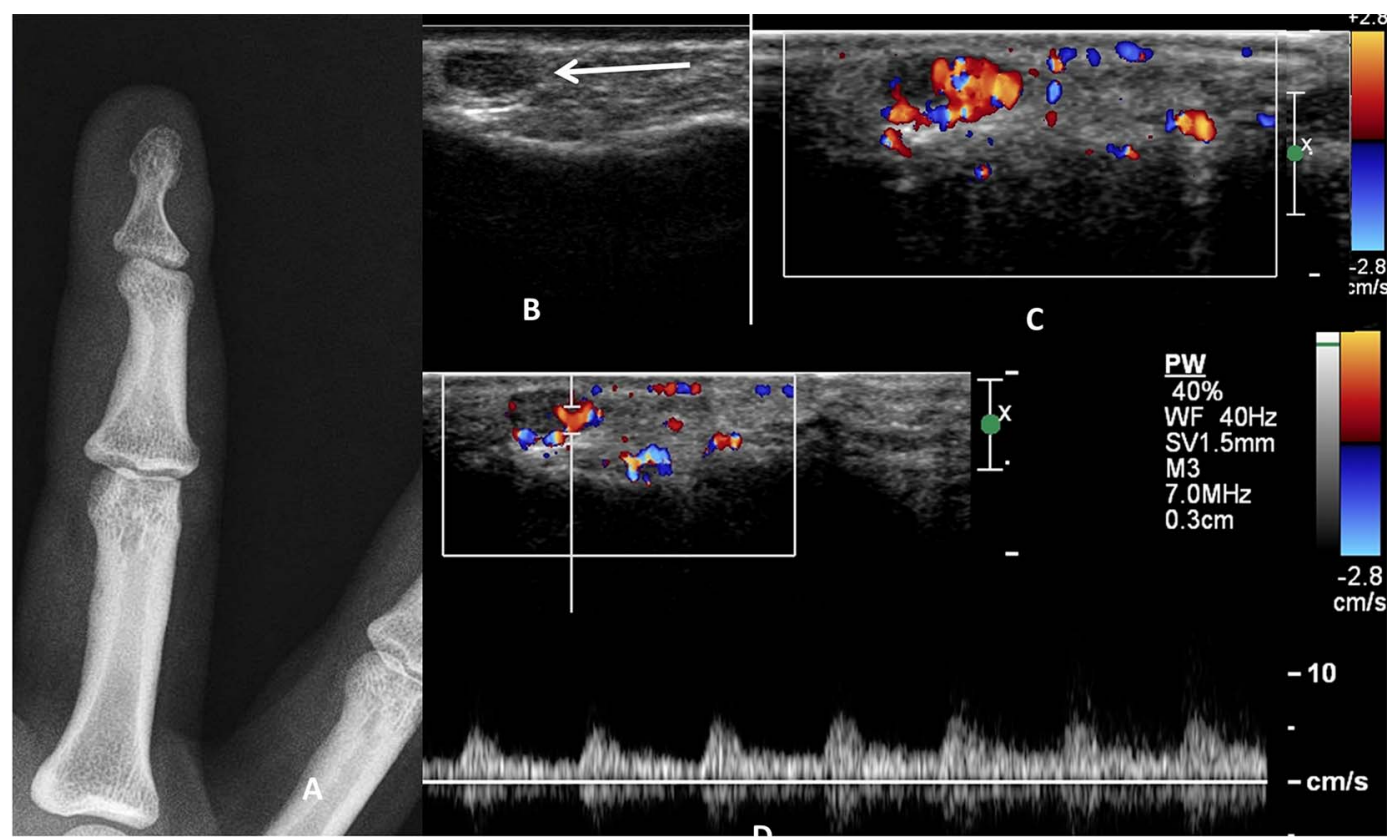

Figure 1 Radiograph of right middle finger (A) showing focal scalloping of lateral aspect of terminal phalanx with no obvious soft tissue component or bone destruction. Grey scale ultrasound image from the lateral aspect (B) showing a small oval homogeneously hypoechoic lesion in the subungual soft tissue. On colour Doppler (C) the lesion showing intense internal vascularity. Pulse wave Doppler (D) showing arterial waveforms.
Shenoy PM, Maddukuri S B, et al. BMJ Case Rep Published online: [please include Day Month Year doi:10.1136/bcr-2014205649

CrossMark 
Figure 2 The lesion is

homogeneously isointense on T1 (A), hyperintense on $\mathrm{T} 2$ (B) and showing postcontrast images (C-E). These images are precisely localising the lesion along the dorsolateral aspect of the phalanx. homogeneous enhancement in
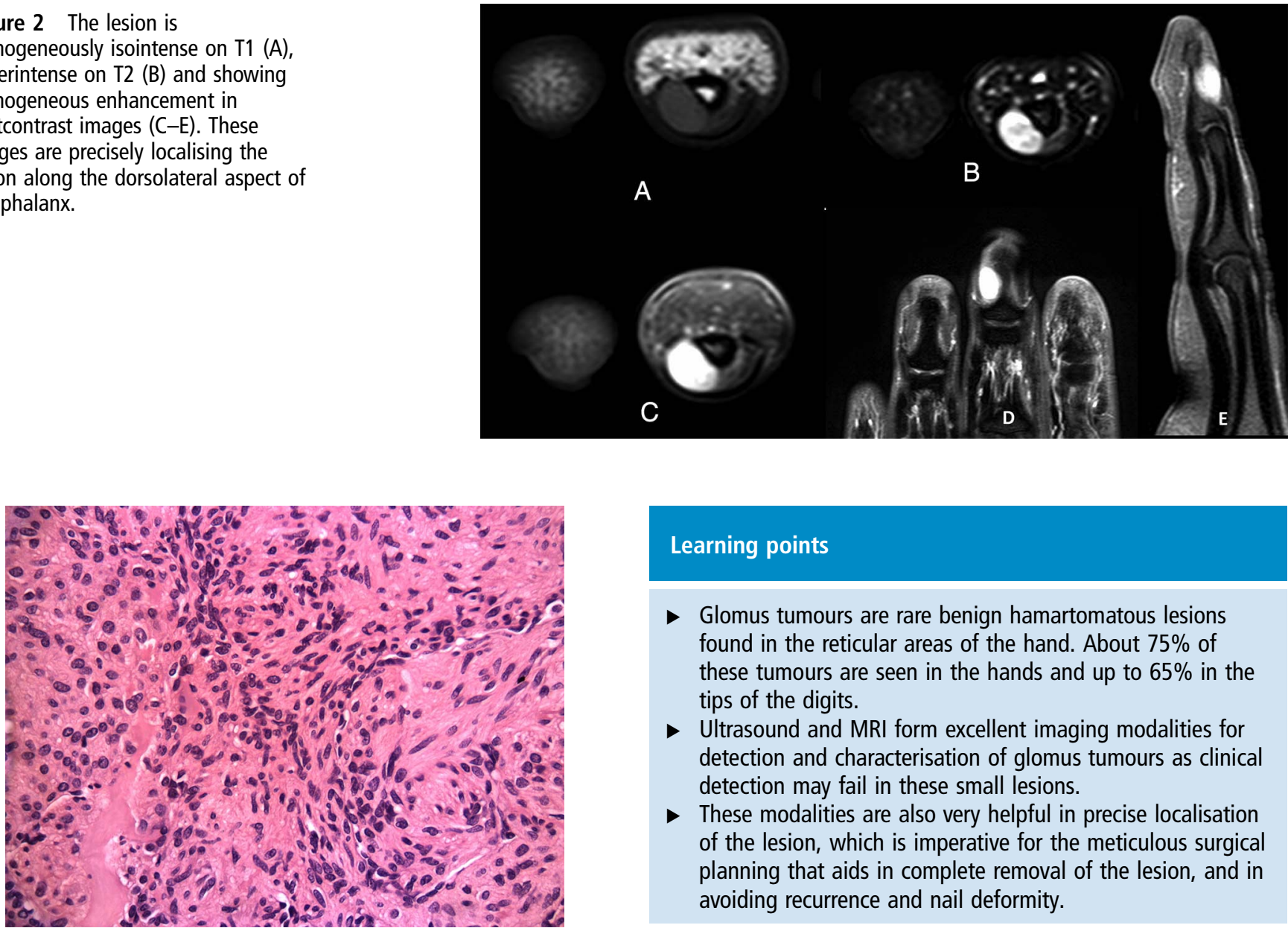

Figure 3 Histopathological section showing numerous vascular channels that are surrounded by aggregates of round epithelioid cells containing eosinophilic cytoplasm confirming it as a glomus tumour.

Acknowledgements Dr Manna Valiathan, Professor, Department of Pathology, Kasturba Medical College, Manipal.

Competing interests None.

Patient consent Obtained.

\section{Learning points}

- Glomus tumours are rare benign hamartomatous lesions found in the reticular areas of the hand. About $75 \%$ of these tumours are seen in the hands and up to $65 \%$ in the tips of the digits.

- Ultrasound and MRI form excellent imaging modalities for detection and characterisation of glomus tumours as clinical detection may fail in these small lesions.

- These modalities are also very helpful in precise localisation of the lesion, which is imperative for the meticulous surgical planning that aids in complete removal of the lesion, and in avoiding recurrence and nail deformity.

Provenance and peer review Not commissioned; externally peer reviewed.

\section{REFERENCES}

1 Carroll RE, Berman AT. Glomus tumors of the hand: review of the literature and report on twenty-eight cases. J Bone Joint Surg Am 1972;54A:691-703.

2 Dinesh $\mathrm{E}$, Terence $\mathrm{T}$, Ruben J, et al. Subungual glomus tumor: magnetic resonance imaging and treatment: a case report. Malays Orthop J 2011;5:48-51.

3 Abdelmohsen K, Aboueldahab Hossam Y, et al. Glomus tumor of the fingers: accurate preoperative localization as a prerequisite to avoid tumor recurrence. Egypt $J$ Plast Reconstr Surg 2011;35:113-20.

Copyright 2014 BMJ Publishing Group. All rights reserved. For permission to reuse any of this content visit

http://group.bmj.com/group/rights-licensing/permissions.

BMJ Case Report Fellows may re-use this article for personal use and teaching without any further permission.

Become a Fellow of BMJ Case Reports today and you can:

- Submit as many cases as you like

- Enjoy fast sympathetic peer review and rapid publication of accepted articles

- Access all the published articles

- Re-use any of the published material for personal use and teaching without further permission

For information on Institutional Fellowships contact consortiasales@bmjgroup.com

Visit casereports.bmj.com for more articles like this and to become a Fellow 